\title{
Studi Ruang Publik Apartemen Berbasis Behaviour Setting
}

\author{
Prasetyo Wahyudie \\ Fakultas Teknik Sipil dan Perencanaan, Jurusan Desain Interior \\ Institut Teknologi Sepuluh Nopember \\ prasetyo@interior.its.ac.id
}

\begin{abstract}
Abstrak
Saat ini, pertumbuhan penduduk yang semakin meningkat di perkotaan dan keterbatasan lahan mengakibatkan perkembangan pemukiman banyak berubah dari landed houses menjadi vertical houses (Apartemen, Rumah Susun, Kondominium dll). Pada perubahan ini di tenggarai akan terjadi pula perubahan perilaku, sosioal budaya dan lainnya. Perubahan ini akan menyebabkan ketidak nyamanan dalam menghuni hunian vertikal tersebut, terutama dalam perilakunya. Perubahan ini perlu diteliti untuk mengurangi shock culture pada apartemen menengah kebawah, khususnya guna didapatkan cara adaptasi yang optimal dari perubahan perilaku dan budaya penghuni apartemen.

Salah satu cara untuk meneliti perubahan ini adalah dengan menggunakan metoda behaviour setting dalam menstudi perilaku penghuni apartemen. Ruang publik dipilih karena merupakan ruang komunal dimana para penghuni apartemen berinteraksi satu sama lainnya. Hasil penelitian menunjukkan bahwa perilaku di dalam ruang public, khususnya koridor, lobby, play ground menunjukkan bahwa ruang tersebut dirasakan sebagai ruang yang mengarah sebagai ruang perpanjangan dari hunian mereka. Ruang publik; kolam renang, minimart, apotik dan lainnya dimaknai sebagai fasilitas biasa selayaknya fasilitas pada daerah perumahan.
\end{abstract}

Kata kunci: Behaviour setting, Ruang Publik, adaptasi, perilaku, apartemen

\section{PENDAHULUAN}

Saat ini, terjadi pertumbuhan penduduk di perkotaan yang semakin meningkat. Kondisi ini menyebabkan munculnya berbagai macam permasalahan. Keterbatasan lahan dan tuntutan akan kedekatan dengan tempat kerja akan memaksa penduduk yang mempunyai sosial budaya tinggal di rumah landed house untuk bergeser ke perumahan vertical houses. vertical houses seperti rumah susun, apartemen, kondominium dan lainnya. Pada penelitian ini akan lebih difokuskan kepada hunian apartemen.

Apartemen memiliki arti sebagai sebuah blok bangunan yang bagian dalamnya diberi sekat-sekat hingga menjadi sejumlah ruang yang disewakan atau biasanya dipasarkan dengan sistem strata title. Strata title adalah hak bukan kepemilikan atas tanah, melainkan hak milik atas satuan rumah susun (apartemen).

Pada sebuah apartemen dibutuhkan pola ruang yang baik dan nyaman bagi penghuni, hal ini dikarenakan hunian apartemen tidak seperti hunian horizontal (landed houses), dimana hunian vertikal tidak dapat dirubah kondisi fisik bangunannya (dikurangi atau ditambah) seperti hunian landed houses dan luasannya sudah tetap/fixed. Dengan demikian, pola ruangan di setiap unit dari apartemen harus sesuai dengan kebutuhan serta aktifitas dari penggunanya. Sebuah apartemen pada umumnya memiliki beberapa unit yang didesain berdasarkan type ruangan. Type ruangan tersebut dapat dilihat dari kebutuhan jumlah penghuni serta fasilitas yang ditawarkan di dalamnya. Lebih jauh lagi, jumlah penghuni unit hunian sangat berpengaruh dengan luasan ruangan.

Pada perubahan ini di tenggarai akan terjadi pula perubahan perilaku, sosioal budaya dan lainnya. Perubahan ini akan menyebabkan ketidak nyamanan dalam menghuni hunian vertikal tersebut, terutama dalam perilakunya. Perubahan ini perlu diteliti untuk mengurangi shock culture pada apartemen menengah kebawah, khususnya guna didapatkan cara adaptasi yang optimal dari perubahan perilaku dan budaya penghuni apartemen.

Pada perubahan ini di tenggarai akan terjadi pula perubahan perilaku, sosioal budaya dan lainnya. Perubahan ini akan menyebabkan ketidak nyamanan dalam menghuni hunian vertikal tersebut, terutama dalam perilakunya. Perubahan ini perlu diteliti untuk mengurangi shock culture pada apartemen menengah kebawah, khususnya guna didapatkan cara adaptasi yang optimal dari perubahan perilaku dan budaya penghuni apartemen.

Penghuni yang memilih tinggal di apartemen pada dasarnya memiliki aktifitas yang padat sehingga membutuhkan penataan hunian yang simpel dan praktis. Selain itu pertimbangan yang lain diantaranya karena letaknya yang strategis di tengah perkotaan dekat dengan tempat kerja, pusat hiburan dan perbelanja untuk memenuhi segala keburtuhannya. Selain letaknya yang strategis, fasilitas yang disediakan apartemen juga sangat memudahkan aktifitas sehari-hari dan mendukung kenyamanan penghuninya. Fasilitas yang biasanya ditawarkan oleh pihak apartemen mencakup kebutuhan dari para penghuni seperti; area olahraga yang dilengkapi kolam renang dan gym, pertokoan yang menjual berbagai macam untuk memenuhi aneka kebutuhan primer atau tersier, area parkir serta fasilitas penjagaan keamanan disetiap lantai apartemen (baik dari pos 
yang berjaga di luar apartemen, lift yang diberikan kode keamanan sehingga tidak mudah bagi non penghuni untuk dapat mengakses ke area privat) dengan tujuan agar penghuninya merasa nyaman dan aman.

\section{TINJAUAN PUSTAKA}

Rumah merupakan kebutuhan pokok dari manusia untuk berlindung dari cuaca dan bahaya yang mengancam. Menurut Poespowardojo, saat ini rumah mempunyai fungsi sebagai; tempat tinggal, sarana untuk mencapai ketrentaman dan tempat kembali dari rutinitas sehari hari yang dijalani, serta tempat untuk memulihkan jiwa dan raga maupun pendidikan budaya [1]. Lebih jauh lagi, bentuk rumah dapat dilihat dari lima aspek yang mempengaruhinya [2] antara lain dari; cara menjalankan aktifitas dasar, struktur keluarga, peran gender, privasi dan proses sosial. Sementara itu, Norberg-Schutz [3] menunjukkan bahwa bentuk bangunan dapat dilihat dari parameter; kontrol fisik, kerangka aktifitas, sosial mileu dan simbolisasi kultural.

\subsection{Apartemen}

Salah satu pilihan rumah tinggal yang banyak dikembangkan pada saat ini adalah apartemen. Apartemen menjadi hunian yang saat ini pembangunannya banyak dijumpai di pusat kota-kota besar, apartemen dibangun sebagai salah satu penyelesaian permasalahan hunian di kota kota besar. Permasalahan semakin sempitnya lahan permukiman di kota-kota besar dan banyaknya permintaan akan rumah tinggal yang dekat dengan tempat kerja membuat bangunan hunian vertikal ini banyak diminati masyarakat kota guna mendukung efisiensi dan efektifitas dari aktifitas kesehariannya yang sangat sibuk. Harga unit apartemen yang relatif lebih murah dari landed house membuat apartemen semakin banyak diminati.

Dalam KBBI, apartemen diartikan sebagai tempat tinggal (terdiri atas kamar duduk, kamar tidur, kamar mandi, dapur, dan sebagainya) yang berada pada satu lantai bangunan bertingkat yang besar dan mewah, dilengkapi dengan berbagai fasilitas (kolam renang, pusat kebugaran, toko, dan sebagainya). Apartemen juga biasanya dapat disewakan sebagai sebuah hunian sebagaimana menyewakan rumah pada landed house. Sedangkan dalam peraturan perundangan di Indonsia, apartemen termasuk dalam bangunan rumah susun. Lebih jauh lagi, menurut UU nomor 20 tahun 2011, rumah susun (apartemen) didefinisikan sebagai bangunan gedung bertingkat yang dibangun dalam suatu lingkungan yang terbagi dalam bagian-bagian yang distrukturkan secara fungsional, baik dalam arah horizontal maupun vertikal dan merupakan satuansatuan yang masing-masing dapat dimiliki dan digunakan secara terpisah, terutama untuk tempat hunian yang dilengkapi dengan bagian bersama, benda bersama, dan tanah bersama.

Bila ditinjau dari kategori jenis dan besar bangunan apartemen [4], maka apartemen dapat dibagi menjadi; High-Rise Apartement yang merupakan apartemen lebih dari sepuluh lantai yang dilengkapi parkir bawah tanah dilengkapi sistem keamanan juga layanan servise penuh serta biasanya terdapat pada pusat kota, Mid-Rise Apartement yang terdiri dari tujuh hingga sepuluh lantai dan sering dijumpai pada kota satelit, Low-Rise Apartement yang menggunakan tangga sebagai alat transportasi dan biasanya untuk golongan menengah kebawah, serta Walked-up Apartement yang terdiri dari tiga sampai enam lantai serta biasanya disukai oleh penghuni yang mempunyai keluarga besar.

Lebih jauh lagi, jenis apartemen juga dapat dilihat dari tipe unitnya[4] yang dapat dibagi menjadi empat kelompok yaitu; tipe Studio yang hanya memiliki satu ruang dan bersifat multi fungsi serta biasanya dihuni oleh satu orang atau pasangan tanpa anak dengan luas unit antara 20-35 $\mathrm{m}^{2}$, tipe Keluarga yang terdiri dari satu hingga tiga kamar, tipe Loft yang biasanya mempunyai lantai mezzanine, dan tipe Penthouse yang mewah dan mempunyai lift khusus untuk penghuninya. Berikut beberapa contoh gambar layout dari apartemen.
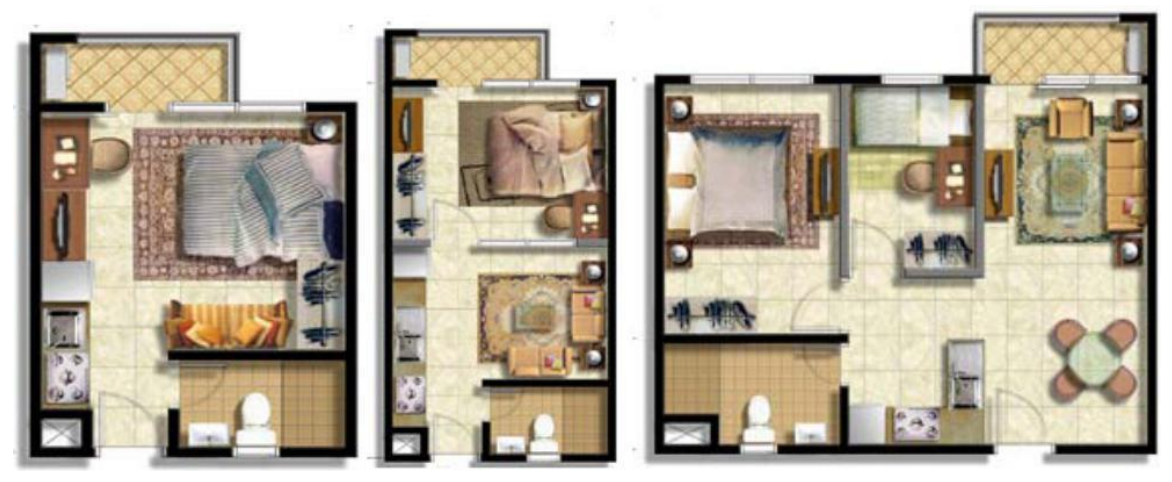

Gambar 1. TIPE UNIT APARTEMEN

Tipe studio dan tipe keluarga satu dan dua kamar yang dijual pada apartemen cosmopolis Sumber : http://www.metro-cosmo.com

\subsection{Behaviour Setting}

Dalam sebuah lingkungan binaan, kemampuan adaptasi dan fleksibilitas tidak dapat dipisahkan dari behavior setting, sehingga dengan beberapa penyesuaian memungkinkan terdapat beberapa pola perilaku yang berbeda yang terjadi pada satu environment (lingkungan) yang sama [5].

Behaviour Setting dapat diartikan sebagai sebuah interaksi antara suatu kegiatan yang dilakukan oleh manusia dengan tempat atau lingkungan dimana kegiatan itu sedang berlangsung. Disini terdapat dua bagian penting yaitu perilaku dan lingkungan yang merupakan faktor dengan hubungan sebab akibat. Didalam hubungan sebab akibat ini terdapat respon persepsi manusia terhadap lingkungan yang mempengaruhi perilaku manusia tersebut. Lebih jauh lagi, perilaku tersebut akan 
menyesuaikan dengan tempat atau ruang dimana manusia tersebut berada. Behaviour Setting diasusmsikan sebagai kombinasi yang stabil dari suatu aktifitas dan tempat, dan terdiri dari [5]; kegiatan saat ini dengan pola perilaku yang sedang terjadi, tata letak (layout) tertentu dalam sebuah lingkungan dengan lingkungan binaan, hubungan kongruen antara keduanya, dan spesifik dalam suatu periode tertentu. [5] juga menyebutkan bahwa setiap individu atau kelompok mempunyai Behaviour Setting yang berbeda, dimana perbedaan ini dipengaruhi oleh aspek; gender,umur, sosial, budaya dan aspek ekonomi.

Roger Barker menyatakan bahwa dalam studi perilaku lingkungan dapat dilihat atas 4 karakter, yaitu; a standing pattern of behavior (perilaku individu), social rules (norma), physical environment (ruang sosial, ruang privasi dll) dan time locus (batasan waktu : jam, hari, bulan dst) [6]. Sehingga nampak jelas bahwa studi perlaku lingkungan merupakan studi perilaku manusia sebagai individu maupun sosial (group komunitas) terhadap lingkungan fisik, selain mengkaji fungsi fisik (needs) juga non fisik.

\section{METODA PENELITIAN}

Dalam penelitian ini, digunakan perpaduan antara metoda kualitaif dan kuantitatif dengan tujuan agar kajian kualitatif dapat lebih dipertanggung-jawabkan secara kuantitatif. Penelitian behavior setting sendiri menuntut untuk penelitian dengan pengamatan langsung akan perilaku dalam beraktifitas didalam sebuah lingkungan bina dalam kurun waktu tertentu, sehingga metoda observasi merupakan inti dari penelitian ini. Untuk mendapatkan kajian yang menyeluruh, maka dibutuhkan data pendukung lewat; pengambilan gambar atau foto, serta pemahaman karakter penghuni melalui teknik wawancara terstruktur serta penyebaran kuesioner. Analisa dan kajian dilakukan berdasar variabel-variabel dari behavior setting, pola ruang, kebutuhan serta aktifitas pengguna apartemen.

\section{HASIL DAN PEMBAHASAN}

Responden sebanyak 78\% menyatakan bahwa dalam melakukan pembelian apartemennya sangat dipengaruhi oleh tipe apartemen yang akan dibeli, serta prospek kedepan dalam hal return of investation dan bentuk arsitektur serta interiornya. 87 $\%$ responden juga setuju dan sangat setuju dengan fasilitas apa saja yang ditawarkan oleh pengembang sebelum membeli apartemen, demikian pula untuk pelayanan yang ditawarkan oleh pengembang apakah telah sebanding dengan harga unit apartemennya.

Sebanyak 74\% responden menyatakan bahwa dalam membeli apartemen, responden dipengaruhi oleh keluarga dalam membeli apartemennya. Kondisi ini menunjukkan bahwa keluarga mempunyai pengaruh yang dominan dalam menentukan apartemen mana yang akan dibeli oleh responden, keputusan keluarga merupakan bagian penting dalam membeli apartemen. Alasan lokasi pekerjaan juga mempengaruhi responden dalam memilih apartemen sebesar 74\%. Yang tidak kalah pentingnya adalah kondisi lingkungan dan keamanan merupakan faktor yang cukup berpengaruh dalam menentukan pilihan membeli apartemen sebesar $83 \%$

Ada sesuatu yang menarik untuk dikaji lebih dalam, dimana mayoritas responden menyatakan bahwa tidak terlalu bangga dengan pilihan untuk tinggal diapartemen sebagai hunian pengganti rumah tinggal. Komunitas sosial sebelumnya ternyata mempengaruhi dalam pertimbangan untuk pindah ke apartemen, kondisi ini menunjukkan bahwa terjadi perubahan perilaku yang kurang dapat diterima sebagai konsekuensi perpindahan dari landed houses ke vertikal houses.Lebih jauh lagi, diperlukan adaptasi dalam perpindahan ini, dan salah satu bentuk adaptasinya adalah bisa dengan mengulang sebagian dari memori lama tentang landed houses ke dalam vertikal houses

Mayoritas responden merasa nyaman dalam melakukan kegiatan kerumah-tanggaan didalam unit apartemennya sebesar $87 \%$. Koridor, lobby, play ground dimaknai sebagi bagian yang dimilikinya dan merupakan bagian dari hunian unit mereka (83\%), namun yang menarik adalah mereka masih merasa harus menjaga penampilan selayaknya berada diluar rumah, dan kondisi ini berbeda dengan yang ada di landed houses. Ketiga ruang publik ini dibutuhkan sebagai kepanjangan dari unit hunian. Sedangkan ruang publik; kolam renang, minimart, apotik dan lainnya dimaknai sebagai fasilitas biasa selayaknya fasilitas pada daerah perumahan pada umumnya.

Hasil pengamatan behaviour setting pada koridor (hingga lift) menunjukkan bahwa koridor kurang nyaman untuk digunakan sebagai kegiatan sehari hari sebagai misal tempat berinteraksi dengan sesama penghuni apartemen, mengasuh anak dan area beraktifitas anak. $100 \%$ orang tua merasa kurang aman dan kurang nyaman untuk membiarkan anak-anak bermain ringan di koridor. Namun $89 \%$ responden menyatakan membutuhkan area koridor sebagai kepanjangan dari area bermain untuk anak-anak mereka. Kondisi ini bukan berarti bertentangan dengan hasil kuesioner dan wawancara serta pengamatan, tetapi lebih menunjukkan bahwa area koridor hingga lift harus didesain sedemikian rupa oleh pengembang guna menjunjang aktifitas yang diinginkan oleh penghuni apartemen.
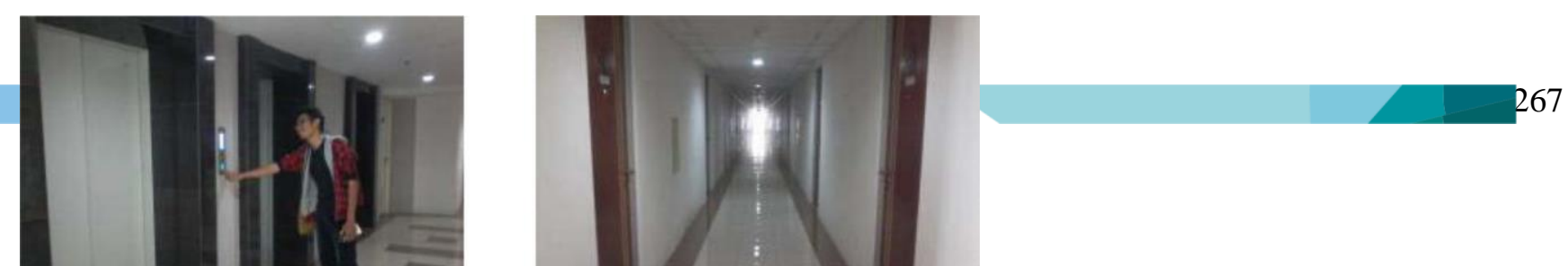


\section{Gambar 2. AREA KORIDOR DAN LIFT}

Koridor dan area lift yang lebih banyak berfungsi sebagai area sirkulasi, dan disatu sisi merupakan harapan dri penghuni untuk bisa dioptimalkan sebagai kepanjangan area bermain dan mengasuh anak

Kondisi yang sama juga ditunjukkan oleh lingkungan lobby. Namun lobby kondisinya lebih baik dari koridor. Lobby masih didesain untuk kegiatan bersantai, membaca dan menerima tamu. Kondisi ini terlihat dalam pengamatan terus menerus yang menunjukkan perilaku bersantai, membaca dan menerima tamu. Terdapat kondisi yang agak mengganggu ketika ada penghuni lainnya yang juga ingin memanfaatkan lobby tersebut. Kondisi ini dapat dioptimalkan dengan menyediakan ruang lobby yang lebih luas dan memperbanyak (menggandakan) fasilitas didalamnya.

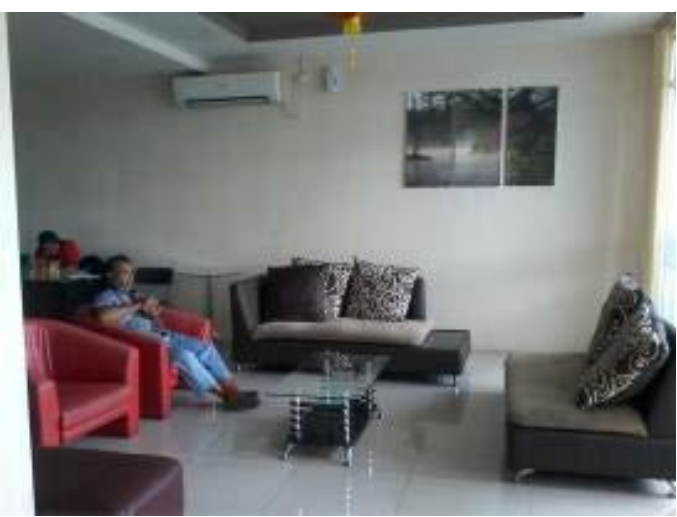

Gambar 3. AREA $L O B B Y$

Salah satu sisi dari lobby yang digunakan untuk bersantai, menerima tamu, membaca dan lainnya

Kondisi lebih baik lagi ada pada play ground. Play ground berfungsi dengan baik, anak anak bermain dan menjalankan aktifitasnya dengan gembira serta nyaman. Pola perilakunya menyebar dan ada beberapa area tertentu yang mempunyai tingkat aktifitas yang lebih padat dibandingkan dengan sisi lainnya. Anak-anak bebas bergerak dan berekpresi, yang mana kondisi ini tidak ditemukan di lobby.

\section{KESIMPULAN}

Apartemen sebagai bentuk vertical houses merupakan salah satu bagian dari gaya hidup masyarakat kota yang memerlukan hunian praktis, efektif (dekat tempat bekerja), bernilai investasi tinggi serta mengedepankan privasi penghuni. Bentuk fisik bangunan apartemen di desain sedemikian rupa untuk memfasilitasi kebutuhan penghuninya sebagai daya tarik dari sisi pemasaran dan kebanggan bagi penghuni apartemen. Fasilitas dan ruang publik juga sangat berpengaruh bagi penghuni apartemen.

Metoda behaviour setting dapat digunkan dalam menstudi perilaku penghuni apartemen . Hasil penelitian menunjukkan bahwa perilaku di dalam ruang publik, khususnya koridor, lobby, play ground menunjukkan bahwa ruang tersebut dirasakan sebagai ruang yang mengarah sebagai ruang perpanjangan dari hunian mereka. Ruang publik; kolam renang, minimart, apotik dan lainnya dimaknai sebagai fasilitas biasa selayaknya fasilitas pada daerah perumahan.

Diperlukan perubahan setting di dalam koridor dan lobby agar sesuai dengan harapan penghuni dan diperlukan pula desain yang menyambung dan mengingatkan akan landed houses.

\section{DAFTAR PUSTAKA}

[1] D. HIJRIWATI, "Implementasi Pencanangan Kebijakan Kawasan Bebas Kumuh Melalui Hunian Model Rusunawa di Kota Pekalongan,” J. Ilmu Pengetah. dan Teknol., vol. 22, no. 1, 2012.

[2] R. A, House Form and Culture. Englewood Cliffs, New Jersey: Prentice-Hall, Inc, 1969.

[3] S. BAHRI, “Rumah Susun sebagai Bentuk Budaya Bermukim Masyarakat Modern,” J. Sist. Tek. Ind., vol. 6, no. 3, 2005.

[4] I. AKMAL, Menata Apartemen. Jakarta: Gramedia Pustaka Utama, 2007.

[5] J. LANG, Creating Architectural Theory: The Role of The Behavioral Sciences in Environmental Design. New York: Van Nostrand Reinhold Company, 1987.

[6] S. B. A. WAHYUDIE. P, "Personalization as Sustainable Living in Public Space of Apartment," in International Conference of Creative Industri, 2015. 